\title{
Non-Native Pre-Service English Teachers' Narratives about Their Pronunciation Learning and Implications for Pronunciation Training
}

\author{
Chin-Wen Chien (Corresponding author) \\ Department of English Instruction, National Hsinchu University of Education \\ No. 521, Nanda Road, Hsinchu City 300, Taiwan \\ E-mail: chinwenc@ms24.hinet.net
}

Received: 13-02-2014

Accepted: 29-03-2014

Published: 01-07-2014

doi:10.7575/aiac.ijalel.v.3n.4p.177

URL: http://dx.doi.org/10.7575/aiac.ijalel.v.3n.4p.177

\begin{abstract}
This study analyzes 58 non-native pre-service elementary school English teachers' narratives about their pronunciation learning and teaching. Two important findings emerge in this study. First, participants did not have the same attitude toward their roles as non-native English speakers regarding pronunciation learning and teaching. Second, regardless of their attitude or roles as non-native English speakers, participants claimed that when they become language teachers in the future, they will apply a variety of instructional strategies to help their potential learners in terms of pronunciation instruction. Four suggestions are provided for pronunciation training in the language teacher education programs.
\end{abstract}

Keywords: language teacher education, narrative, non-native English-speaking teachers (NNESTs), pronunciation

\section{Introduction}

Scholars have been discussing the relevance of teaching pronunciation in English language teaching (Chiu, 2008; Harmer, 2007). Harmer (2007) identifies the importance of pronunciation instruction as "Pronunciation teaching not only makes students aware of different sounds and some features, but can also improve their speaking immeasurably" (p. 248). Celce-Murcia, Brinton, and Goodwin (1996) claim that non-native speakers of English need to achieve a "threshold level of pronunciation" to be understood and to minimize oral communication problems (p. 3). Pronunciation needs to be taught and deserves more attention in a language course.

In the past 25 years, pronunciation instruction has shifted the focus from segments to suprasegmental (Avery \& Ehrlich, 2002; Levis, 2005; Morley, 1991). In Taiwan, the Kenyon \& Knott (KK) phonetic symbols have been regarded as the major tool in teaching pronunciation to English as a Foreign Language (EFL) learners for about thirty years (Lin, 2001). English has been taught compulsorily in Taiwan to fifth and sixth graders and then from third to sixth graders in 2001 and 2006 respectively. Phonics has been taught in elementary school English classes.

Most current studies on pronunciation mainly focus on analyzing different aspects of spoken discourse, comprehension, and intelligibility, as well as attitudes and stereotyped assumptions of different accents (Sifakis \& Sougari, 2005). However, there is limited research discussing elementary school EFL teachers' practices and beliefs with regard to pronunciation teaching (Chiu, 2008; Liu, 2010). Kleinsasser (1993) calls for the teaching profession to "capture the essence and nuance of teachers' thoughts, beliefs, and actions in their workplace" (p. 372). This study aims to analyze 58 non-native pre-service elementary school English teachers' narratives about pronunciation learning and teaching. Based on the participants' narratives about their pronunciation learning, suggestions are provided for pronunciation training in the language teacher education programs.

\section{Literature review}

The literature review discusses the following three issues: pronunciation and phonics instruction, EFL learners' perception of pronunciation learning, EFL teachers' perception of pronunciation instruction, and the roles of native English-speaking teachers (NESTs) or non-native English-speaking teachers (NNESTs) in pronunciation instruction.

\subsection{Pronunciation and Phonics Instruction}

The teaching of English to fifth and sixth graders in Taiwan's elementary schools became compulsory in the fall semester of 2001 and this was extended to include third and fourth graders in 2005 (Ministry of Education, 2001, 2005). Phonics is mandated to be taught in elementary school English classes to help learners learn to read.

Studies show that teaching pronunciation through phonics is more effective (Huang, 2002; Hung, 1998). Fifth graders in Hung's (1998) the phonics group performed significantly better than those in the K. K. group in the oral pronunciation test. Phonics instruction has positive effects on first-year junior high school students' acquisition of phonological awareness. On the other hand, some studies show that the K. K. phonetic system is more effective in terms of pronunciation learning and instruction (Chu, 2006; Hsieh, 2009; Liu, 2009). However, some studies show 
that there are no significant differences between learners' pronunciation performance, regardless of phonics or K. K. phonetic system instruction (Hsu, 2003; Yeh, 2005). Most studies show that learners benefit from the combination of both types of instruction (Chung, 2011; Hsu, 2000; Lin, 2001).

\subsection{EFL Learners' Perception of Pronunciation Learning}

Tseng's (2011) study used Cenoz and Lecumberr's (1999) survey to investigate 106 Taiwanese English learners' perceptions of English pronunciation acquisition. This study concludes that participants considered that pronunciation teaching and learning is important for their development of communicative competence. They also believed that acquiring a native-like accent might influence intelligence.

The majority of Chinese college students, 82 percent, surveyed in He and Miller's (2011) study, preferred trying to sound like a native speaker. Moreover, $79.6 \%$ percent of the participants believed that they could achieve native-like proficiency and were able to speak Standard English.

\subsection{EFL Teachers' Perception of Pronunciation Instruction}

Lin's (2010) study investigated eight elementary English teachers' beliefs and practice of pronunciation teaching and learning. These teachers in Yunlin County believed that pronunciation, particularly segmental pronunciation, was important in elementary English learning. They used phonics as a means to teach pronunciation. They also claimed that pronunciation classes they took in college did not help their pronunciation instruction very much.

Chiu's (2008) study focuses on the teaching approaches and beliefs about pronunciation teaching of four elementary school NNESTs and four NESTs in Taipei City. All participants claimed that they taught pronunciation and their instruction involved mostly segmental features. Only one teacher claimed that her instruction focused on suprasegmental features. The NESTs relied more on anecdotes, personal experiences and language examples to explicate their ideas while the NNESTs applied more pedagogical and linguistic terminology in their narration. While the NESTs take an intuitive-imitative approach with no explicit instruction or explanation of individual linguistic features, the NNESTs took a more linguistic-analytical approach and conceptualized explicitly.

\subsection{Roles of NNEST or NESTs in Pronunciation Instruction}

Language learners prefer to learn speaking and pronunciation from NESTs, because they feel that they can learn real and correct English from NESTs (Butler, 2007; Chang, 2013; Kasai, Lee, \& Kim, 2011; Lasagabaster \& Sierra, 2005; Mahboob, 2004; Meadows \& Muramatsu, 2007; Kelch \& Santatn-Williamson, 2002; Sung, 2009; Tang, 1997). Kelch and Santan-Williamson (2002) investigated 56 English as a second language (ESL) students' attitudes towards NESTs and NNESTs in the United States and concluded that the students showed a preference for NESTs when it came to learning speaking, listening, and pronunciation. NESTs are considered to have a standard accent and pronunciation. Participants in Hadid's study claim that NESTs are perceived as emphasizing more correct pronunciation than NNESTs (Hadid, 2004). However, Taiwanese college students in Wu and Ke's (2009) study complained that NESTs seldom corrected their mistakes and pronunciation during oral practice.

Most NNESTs are criticized for their pronunciation and accent (Bastug, 2010; Beckett \& Stiefvater, 2009; Chang, 2013; Corcoran, 2011; Faez, 2010; He \& Miller, 2011; Karakuzu \& Akdoğan, 2010; Miyasone, 2007; Shibuya, 2012; Vodopija-Krastanovic, 2012). According to Levis (2005), accent is intertwined with race in determining professional identity (p. 375). Some student teachers in Vodopija-Krastanovic's (2012) study criticized their teachers' non-native pronunciation and questioned the lecturers' professional identity as "Some of our teachers have awful pronunciation ... you have to know how to speak English, and pronunciation is part of that" (p. 216). NNESTs were criticized as being unable to teach oral communication skills, and such weaknesses may be due to the belief of learners that in order to acquire a "true" and "correct" pronunciation, they must follow native speaker models (Mahboob, 2004). One student surveyed in Shibuya's (2012) study displayed negative a attitude toward NNESTs by saying, "His English is not real. I cannot learn real pronunciation" (p. 131).

All participants in Beckett and Stiefvate's (2009) study complained that ESL students should acquire native-like accents, which cannot be learned from NNESTs (p. 37). One participant further elaborated his idea: "Most international students, their pronunciation is not good. And we want something to improve on our pronunciation or their grammar and if their teacher is native spoken maybe is good to ask" (p. 37). NNESTs, identified as "internationally educated teacher candidates" in Canada in Faez's (2010) study, identified that accent and mispronunciation of certain words made them feel humiliated in the practice teaching sessions. Therefore, when the primary pedagogical goal is to teach EFL learners oral proficiency, NNESTs are required to have native-like proficiency and pronunciation in the target language (English) (Corcoran, 2011).

NNESTs are not only deeply conscious of their accents but also wish that they spoke English like NESTs (Corcoran, 20111; Edwards, 2009; Jenkins, 2005; Llurda \& Huguet, 2003; Muramatsu, 2008). Participants in Jenkins' (2005) study considered a native speakers' accents to be "good," "perfect," "correct," "proficient," "competent," "fluent," "real," and "original English"; on the other hand, they regarded non-native speakers' accents as "not good," "wrong," "incorrect,", "not real," "fake," "deficient," and "strong" (p. 7). Participants in Edwards' (2009) study complained that their non-native speaker's accent was their disadvantage, as "Sometimes I couldn't pronounce words correctly"; theirs was "incorrect pronunciation" (p. 6). One teacher in Reis' (2011) study stated as follows: 
I don't think I would be confident to teach American pronunciation in an ESL context because I don't think my pronunciation is American-like, so if this course is called American pronunciation, I don't think I'm a good model in providing students with this so-called American pronunciation (p. 152)

A Taiwanese NNEST claimed that "Although I feel comfortable to be told that I did not have to be native-like, I would definitely feel upset if I could not reach my own expectation in pronunciation" (Holliday, 2005, p. 9). A Brazilian teacher in Corcoran's (2011) study claims that "That's my goal to speak like a NEST ... I am going to Canada...and my main objective in going there is to improve my pronunciation because I would like to be a native speaker ..." (p. 14).

Teachers' personal conceptions of their teaching and learning affect their management of teaching and learning (Andrews, 2003). Andrews (2003) proposes a model on the relationship between teachers' language awareness, language proficiency, and pedagogical content knowledge as in Figure 1 (p. 91). Andrews argues that teachers' language awareness have a significant impact on how teachers handle language. Teachers need to be equipped with different types of knowledge base including: subject-matter cognitions (i.e. knowledge about language), language proficiency (knowledge of language), knowledge of learners, knowledge of pedagogy, knowledge of the curriculum, and knowledge of the context.

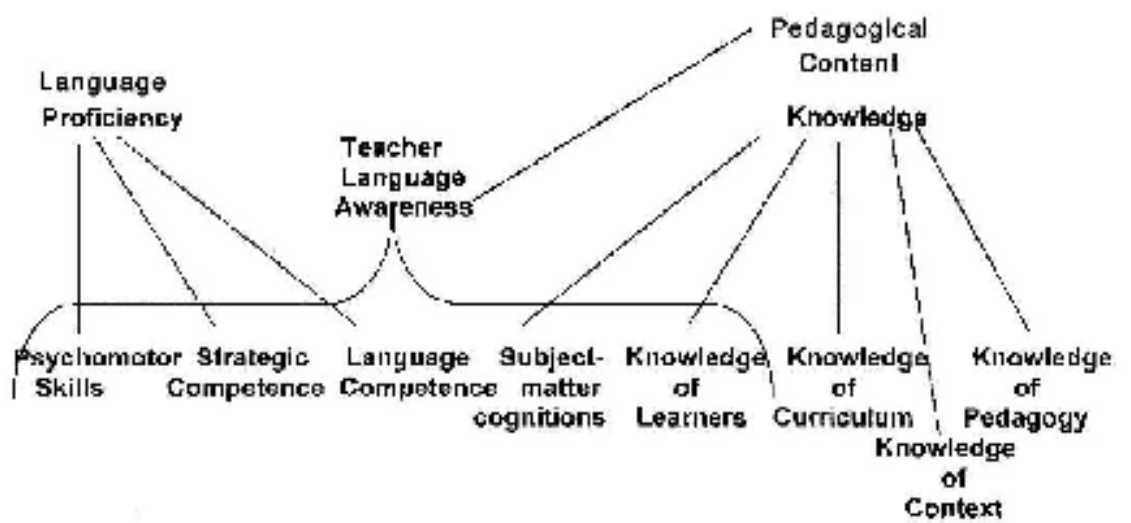

Figure 1. Relationship Between Teacher Language Awareness, Language Proficiency, and Pedagogical Content Knowledge

Jenkins (2005) claims that "past experiences, both classroom and social, factors in their present situation, and their assessment of their future chances of success may combine to affect their attitudes to English at the deeper level" (p. 541). Nine novice teachers, particularly NNESTs in Warford and Reeves's (2003) study connected their experiences as learners to their experiences as teachers NNESTs. Therefore, based on the above literature review, pre-service language teachers' education, their pronunciation learning experience, English education policy, and their intuition or physical constraints affect their beliefs, competence, and identity on pronunciation learning and teaching, as revealed in Figure 2.

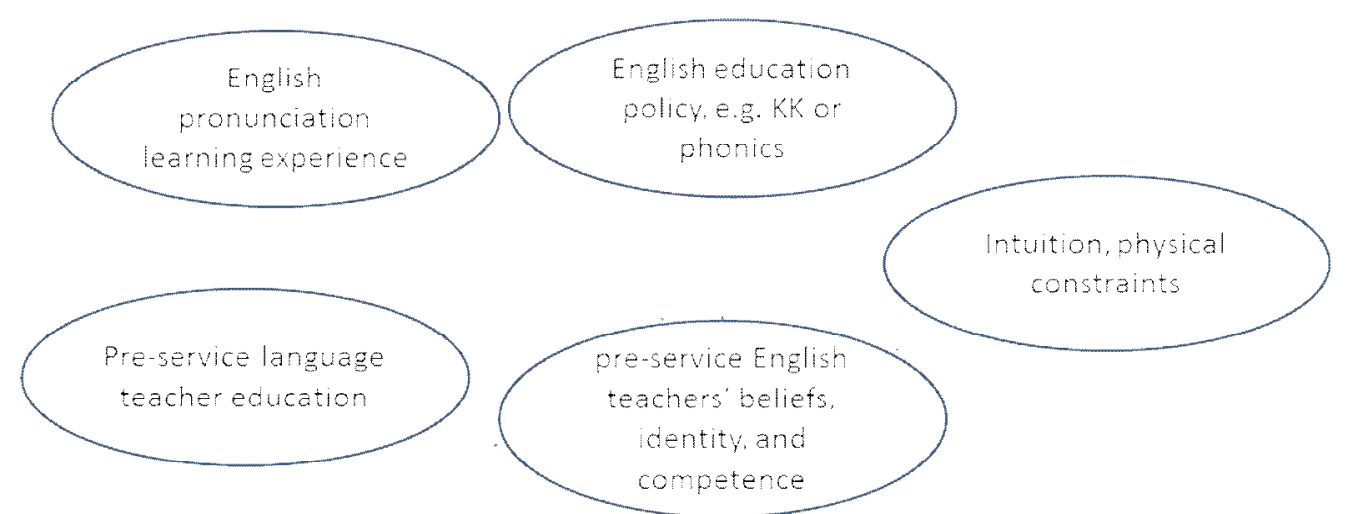

Figure 2. Factors that Affect Pre-service English Teachers' Beliefs and Competence on Pronunciation Learning and Teaching

Pre-service teachers' perceptions and cognitions influence their teaching practice (Mcneely \& Mertz, 1991). Most current studies focus on learners' learning and teachers' perception of NESTs and NNESTs in terms of pronunciation. Most studies use survey or interviews (Butler, 2007; Chang, 2013; Chiu, 2008; Corcoran, 2011; He \& Miller, 2011; Kasai, Lee, \& Kim, 2011; Kelch \& Santatn-Williamson, 2002; Lasagabaster \& Sierra, 2005; Lin, 2010; Mahboob, 2004; Meadows \& Muramatsu, 2007; Reis, 2011; Sung, 2009; Tang, 1997; Tseng, 2011), but very few studies use narrative stories as their research method. This study uses pre-service teachers' roles as both language learners and language teachers to discuss their perception of pronunciation instruction. 
In the past decade, narrative and the practice of narrative research has gained popularity in TESOL (Barkhuizen, 2008, 2009, 2010, 2011; Golombek \& Johnson, 2004; Tsui, 2007). Researchers employ narrative research to study different issues such as teacher and learner identity, teacher education, language pedagogy, etc. in the field of TESOL (Barkhuizen, 2011). Through narrative writing and analysis, language teachers can make sense of their teaching and learning experience (Barkhuizen, 2011; Barkhuizen \& Benson, 2008). Therefore, narratives were used in this study to make sense of participants' learning experience on English pronunciation.

This paper discusses the following issues: (1) How did the pre-service English teachers learn English pronunciation? (2) What were participants' common pronunciation problems and how did they overcome these problems? (3) What was the influence of their role as non-native English speakers on their pronunciation learning and teaching?

\subsection{Setting and Participants}

The participants were 58 pre-service teachers: 53 were females and 5 males with an average of 20.2 years. The majority of the participants were English majors consisting of 27 juniors and 20 seniors. Eight participants were from the Department of Education including one graduate student with major in Education, four juniors with major in Education, and three with major in special education. Three participants majored in music. These pre-service English teachers simultaneously enrolled in a Teaching Pronunciation class, part of a language teacher education program in a northern city in Taiwan. The pre-service elementary-school English teachers took this class as one of the 26 additional credits for elementary school English teachers. The class met for three hours each week during the period of the study.

\subsection{Data Collection}

The study was conducted over a single semester, from mid-February to May, 2013. The major data in this study were participants' narrative stories. On the first day of the academic year, the instructor explained to the participants the class requirements and assignments. The participants were required to write narrative stories that describe their pronunciation learning experience, their strengths and weaknesses in English pronunciation, strategies on solving pronunciation problems and difficulties, and their role as a non-native English speaker in learning English pronunciation. Participants typed in their narratives in Word and uploaded the assignments to the class's server.

Participants were given five minutes to orally present their narratives in class. They shared their narratives through Word or PowerPoint files. While pre-service teachers presented their narratives, the rests of the class wrote responses to their classmates' narratives. The instructor called one or two participants to respond to the participants' narratives. After the researcher's assistant typed in all responses, these responses were distributed to individual participant.

\subsection{Data Analysis}

Pseudonyms were assigned to each participant to ensure confidentiality. Theoretical lenses were used to analyze the study (Creswell, 2009; LeCompte \& Schensul, 1999). The data was coded in the following three stages. First, the researcher read through all the notes and marked the data by a code (e.g., accent, native-like pronunciation, NEST, NNEST etc.). Secondly, while reading through these codes, the researcher assigned tentative categories (e.g. pronunciation learning experience, problem, roles, etc.). Finally, the data was sorted on the basis of its fit into topics that reflected the research questions, as in Figure 3. 


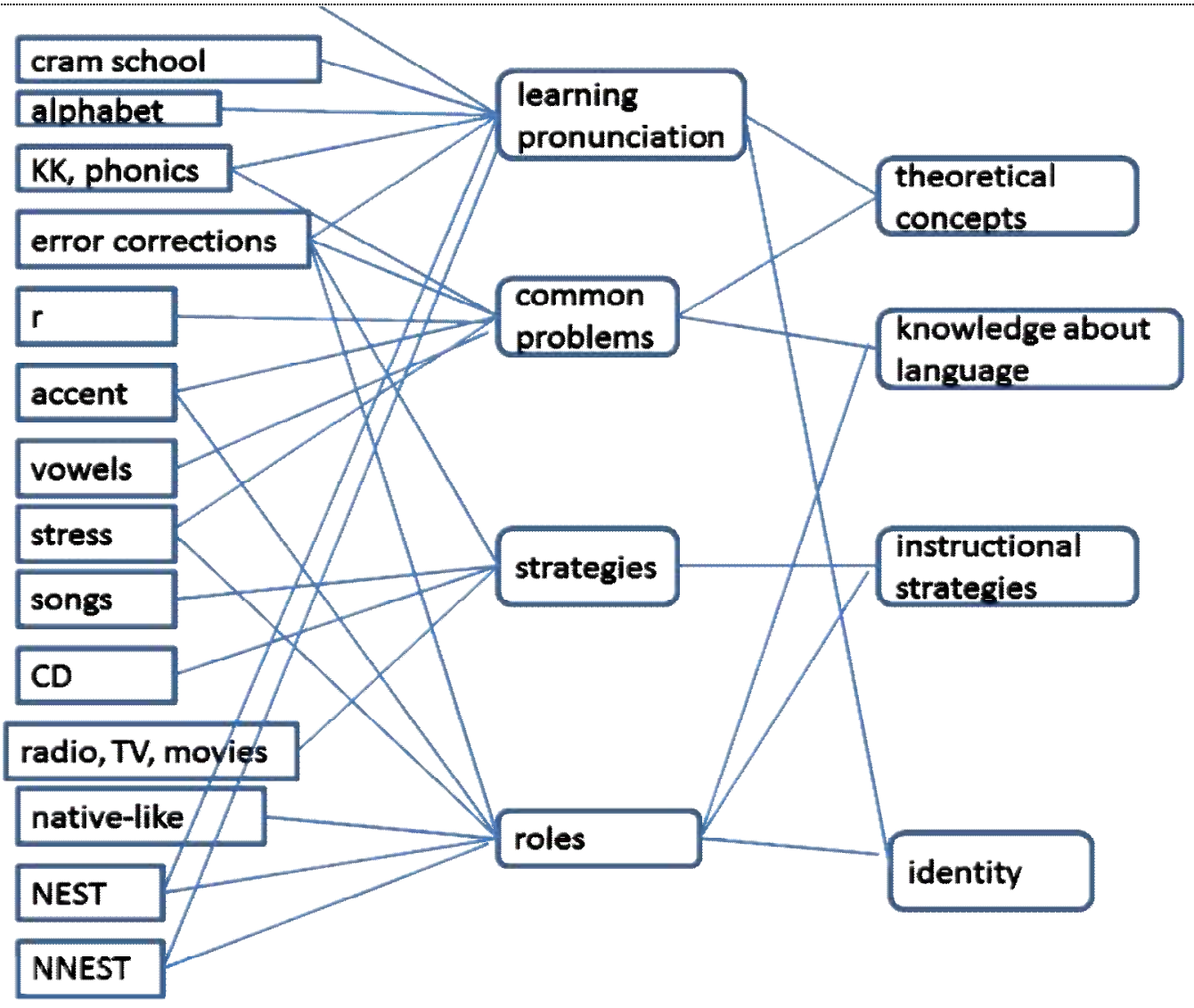

Figure 3. Data Analysis

Member check is a strategy for ensuring the validity and credibility (Merriam, 2009). Following the data collection, member checking was conducted by reporting the preliminary findings to participants, inviting a critical commentary on the findings, and potentially incorporating the critiques into the findings.

\section{Results and Discussions}

Based on the data analysis, the following issues are discussed in terms of English pronunciation learning experience, common pronunciation problems, strategies on overcoming problems, and roles of non-native English speakers on pronunciation learning and teaching.

\section{1 English Pronunciation Learning Experience}

In addition to former English education in the elementary school, 28 of the 58 participants mentioned that they were sent by their parents to the so-called bu xi ban (cram schools or language schools) to learn English pronunciation, as in Examples 1, 2, and 3.

\#1 When I was seven years old, my parents let me go to the cram school to learn English. That was my first time learning English pronunciation.

\#2 My Mom took me to a cram school in the summer vacation, and it is at that time I began learning ABCs in a cram school.

\#3 I went to Hess cram school because my parents wanted me to learn the international language "English" better than others. The first difficult thing of pronunciation I met was the alphabets and the combination of sounds.

Four participants stated that they learned pronunciation from NESTs. Compared with NNESTs, they felt that NESTs put greater emphasis on pronunciation and corrected their pronunciation, as in Examples 4 and 5.

\#4 NNESTs put greater emphasis emphasized more on pronunciation while NNESTs emphasized grammar and spelling. NNESTs called me monthly to give me an oral test. They often corrected my pronunciation.

\# 5 Both NESTs and NNESTs teach in Sesame Street English. NESTs are responsible for teaching pronunciation and oral training.

NESTs are considered to possess a standard accent and pronunciation. NESTs are ideal models for language learners to imitate and are better able to encourage their learners to speak aloud. Therefore, their instruction focuses more on speaking, listening, and pronunciation than NNESTs. Compared with NESTs, NNESTs have a more structured approach to teaching grammar and are good at addressing the grammatical difficulties that language learners encounter (Benke \& Medgyes, 2006; Hadid, 2004; Kelch \& Santan-Williamson, 2002; Wu \& Ke, 2009). Moreover, NNESTs are more serious and severe in managing learners' errors (Chang, 2013). Taiwanese college students in $\mathrm{Wu}$ and Ke's (2009) study complained that NESTs seldom corrected their mistakes and pronunciation during the group discussion. 
Some participants thought their teacher did not explicitly teach pronunciation or correct their pronunciation, as in Examples 6 and 7. Their teachers used games or drill practices to teach words.

\# 6 The teacher didn't clearly teach us the correct pronunciation of each word and didn't lead us to distinguish the minimal pair of words. The teacher just led us to read words and practice short conversation.

\# 7 When I was in primary school our teacher did not really focus on pronunciation. The only instruction related to pronunciation is continuous repetition of the newly learned vocabularies in each lesson.

Some teachers make little attempt to teach pronunciation because they have too much to focus on in the classes, such as grammar and vocabulary. Moreover, in their opinion, students will acquire pronunciation in the language courses even without a formal pronunciation syllabus and specific instruction (Harmer, 2007). Teachers may doubt how to teach it and many experienced teachers admit to a lack of knowledge of the theory of pronunciation (Kelly, 2000). However, pronunciation teaching not only makes learners aware of different sounds and features, it also helps improve their speaking (Harmer, 2007).

In the narrative story, 28 participants stated that they learned phonics, as in Example 8. A total of 12 students recalled that they learned KK when they first learned English pronunciation, as in Example 9. Some participants learned both phonics and KK, as in Example 10.

\# 8 When I learned English, at beginning, my teacher taught us phonics to read the words.

\#9 My mom sent me to the cram school Joy in English to learn the English ... When the teacher taught me KK symbols, they just asked me to memorize them by doing lots of assignments.

\# 10 Another important thing is when I was learning pronunciation, teachers taught me KK and Phonics.

Like the participants in this study, parents of elementary school pupils send their children to cram school to learn KK phonetic symbols. Some teachers teach elementary school students KK phonetic symbols instead of phonics, because they think students can effectively learn pronunciation through KK phonetic symbols (Chen, 1998; Fu, 1995; Li, 1981; Lin, 2009).

A few participants complained that they got confused about phonics and KK systems, as in Examples 11 and 12.

\#11 First, I always confused when I should use phonics and KK. So I started to learn phonics from her and imitate her pronunciation.

\#12 Then I took a KK lesson and learned phonics. I was confused.

\subsection{Common Pronunciation Problems}

Figure 4 reveals nine different pronunciation problems participants in this study encountered including accent, $\mathrm{r}$, vowels, intonation, word or sentence stress, linking, and consonants. The biggest pronunciation problems these participants had was word stress, followed by linking and vowels.

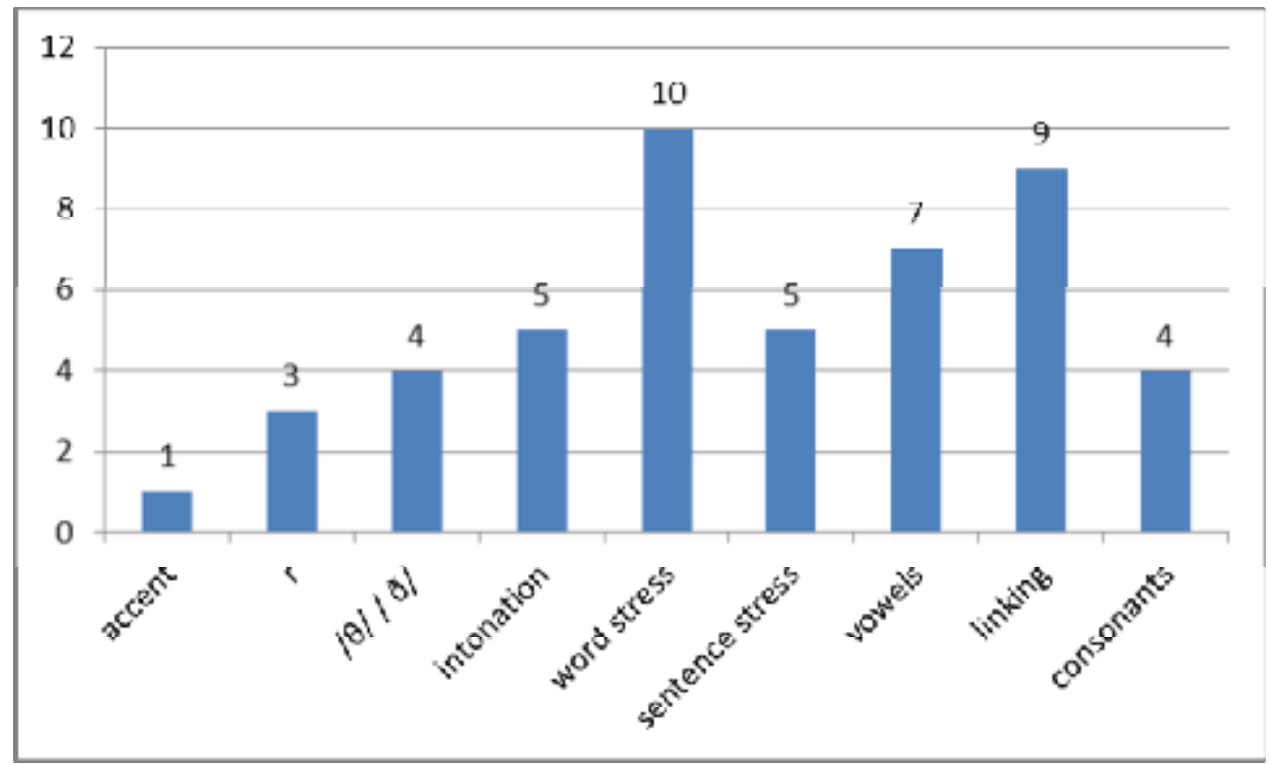

Figure 4. Pronunciation Problems

Mandarin-speaking EFL learners have certain pronunciation difficulties (Huang \& Radant, 2009). The findings in this study are similar to Chen and Yang's (2007). Ninety-four Taiwanese students in Chen and Yang's (2007) study were divided into two groups: proficient and less proficient. Lane's (1997) Focus on Pronunciation and Miller's (2006) Targeting Pronunciation were used to test for their English pronunciation problems. The results showed that proficient learners had difficulties in the perception of focus words, phrases or compounds [e.g. hot dog], and intonation. The top five difficult categories for the less proficient group were: focus words, syllable number, 
perception of tense/ lax vowels, understanding compounds (e.g. hot dog), and perception of mid-tense/lax vowels. Suprasegmentals were challenging for both groups more than segmental aspects of pronunciation.

Participants had problems in word stress because they did not know how to distinguish between the stress of nouns and verbs, as in Examples 13 and 14. Participants also had difficulties in linking, as in Example 15, and vowels, in Examples 16, 17, and 17.

\# 13 The stress will be difficult if one word can be either a verb or a noun, e.g. record, present, etc. I cannot distinguish them.

\#14 I don't know where I should put stress.

\# 15 I have problems with the linking sounds.

\#16 The most embarrassing experience I have is that I pronounce the word blood [blıd] instead of [blud].

\#17 I have problems with the similar sounds /æa/ and /E/.

\# 18 It was hard for me to immediately pronounce and distinguish /e/ and / $/ \mathrm{e} / \mathrm{o} / \mathrm{and} / \mathrm{o} /$.

Mandarin-speaking learners in Taiwan often fail to link words. They tend to separate words by pauses or by insertion of additional sounds at the ends of words. Moreover, the distinction between tense and lax vowels does not exist in Chinese. Chinese-speaking learners have problems in pronouncing the tense and lax vowels of English, such as /e/ vs. / $\varepsilon$ / (Avery \& Ehrlich, 2002; Baker, 1982; Chang, 2001; Chen \& Yang, 2007; Huang, 2001; Swan \&Smith, 1990).

While five participants had problems with intonation, as in Example 19, and with sentence stress, as in Example 20, four students had problems with consonants and / $/$ / and / $/ /$, as in Examples 20 and 21.

\#19 I was criticized for talking like a machine without any intonation.

\# 20 My major pronunciation problem is voiced "th" and the voiceless "th."

\#21 I had problems when I added schwa at the end of voiceless word such as /k/, /t/

Mandarin-speaking learners in Taiwan have difficulty with English intonation because pitch functions differently in Chinese. They also have problems with consonants such as voiced or voiceless th as in "think" and "this," word-final voiceless stop consonants $(/ \mathrm{p} /, / \mathrm{t} /, / \mathrm{k} /)$, voiced vs. voiceless stops in word-final position (/b/, /d/, /g/ vs. /p/, /t/, /k/), word-final nasals, or consonant clusters (Avery \& Ehrlich, 2002; Chen \& Yang, 2007; Wu, 2005). The findings in this study accord with other scholars' research (Chang, 2001; Huang, 2001; Huang \& Radant, 2009; Tzwe, 1987). Tzwe (1987) identified eight inherently difficult English consonants for Mandarin-speaking learners in Taiwan, /3, y, $\theta, \mathrm{z}, \mathrm{s}$, $\mathrm{v}, \mathrm{t}$, f $\mathrm{f} / \mathrm{l}$, while Chang (2001) found that / $3, \mathrm{~s}, \mathrm{z}, \mathrm{v} /$ are more likely to cause pronunciation problems for Taiwanese EFL learners. Huang (2001) concluded that /r, w, l, y, tf, ds, $3 /$ might trouble learners more than other sounds.

Only one participant claimed that they had difficulties with $r$ and accent, as in Examples 22 and 23.

\#22 I was criticized for talking with odd accent.

\#23 I had problems in pronouncing words with $r$ sound.

Mandarin-speaking learners in Taiwan often pronounce word initial $/ \mathrm{r} /$ as $/ \mathrm{w} /$. Sometimes they may substitute $/ 1 /$ for /r/, particularly in initial consonant clusters (Avery \& Ehrlich, 2002; Huang, 2001).

\subsection{Strategies on Overcoming Problems}

These participants identified their pronunciation problems. When asked how they solved their pronunciation problems and difficulties, the strategy used by the majority of the participants was "listen to English songs, CDs, radio programs, TV programs, or movies", as in Examples 24 and 25.

\#24 I watched TV series, listened to broadcasts, practiced conversation with my English teacher merely for their accent.

\#25 I watch more English movies, listen to English songs and radio programs than before, focusing on their pronunciation.

In addition to exposing themselves to an English environment, five participants also claimed that they imitated the native speakers' pronunciation from songs, radio and television programs, or from movies, as in Example 26 and 27.

\#26 I tended to learn by mimicking foreign speakers in cram school or on CDs.

\#27 I learn new vocabulary from the episodes and I'm used to imitating the way the roles speak.

These participants also regarded as useful the linguistic related courses that they took in the teacher education program, as in Example 28.

\#28 The "Linguistic" course also helped me know more about how to pronounce more correctly and beautifully.

Yan (2010) suggests that language teaching training programs for NNESTs should focus on improving their English proficiency and fluency, particularly standard pronunciation. NNESTs should be able to describe the similarities and differences between English and their first language (Liu, 2009). Teachers of pronunciation need a good grounding in theoretical knowledge, practical classroom skills, and have access to good ideas for classroom activities (Kelly, 2000).

Participants also used other strategies such as "looking up words in the dictionary and try to find the stress," "practice and practice more," and "drama performance", as in Examples 29, 30, and 31. Some participants used mirrors while 
learning pronunciation: "I look in the mirror when I practice pronouncing English words." One participant said that she improved her English pronunciation through talking frequently to her language exchange partner.

\#29 I have to look up words in the dictionary and find out the stress.

\#30 The most important thing is "opening my mouth to practice", practices makes perfect.

\#31 My pronunciation improved after the English Drama Performance.

\section{4 Roles of non-native English speakers on pronunciation learning and teaching}

As non-native English speakers, participants in this study have opposite attitudes toward pronunciation learning and teaching. Some participants claim that accent represents one's own identity, as in Example 32.

\#32 Accent represents your identity.

Kumaravadivelu (2008) defines an accent as "no more than one's way of speaking, the way one sounds when speaking, the way one uses sound features such as stress, rhythm, and intonation" (p. 4). Everyone speaks with an accent (Braine, 2010; Kumaravadivelu, 2008). According to Kumaravadivelu (2008), native English speakers' accents may be determined by the geographical area or social class to which speakers belong while non-native English speakers' accent is related to one's mother tongue.

Seven participants think English is used for communication. As long as they can speak clearly with accurate pronunciation, native-like speech is not that important, as in Examples 33 and 34.

\#33 I won't speak English as perfectly as a native speaker does. There'll always be a limitation in my pronunciation because of my physical constriction and the amount of English I am exposed to in my surroundings. However, as long as my "unique accent" won't intervene with my expressing myself, I think, I don't need to change my accent into being "accent-free".

\#34 There is no need to pay too much attention to native-like speech, which does not really exist. What is more crucial than speaking like a native English speaker is to deliver a complete message that can be understood by the interlocutors.

Most participants in this study regard intelligibility rather than accent to be more crucial in communication. This accords with Kumaravadjivelu's (2008) claim for "being understood by an individual or a group of individuals at a given time in a given communicative context" (p. E4).

On the other hand, 14 of the participants claimed that they would work hard to achieve native-like speech, as in Examples 35 and 36 .

\#35 In my opinion, I wish I could speak like a native speaker, so I want to abandon my accent of non-native speaker. Deep down in my heart, I long for becoming a native speaker of English.

\#36 I aim for the standard American accent.

In language classrooms, learners want to get rid of their accents (Levis, 2005). These participants want what Jenkins' (2005) claims is "a native speaker English identity as expressed in a native-like accent" (p. 541). These participants thought that with strong motivation, hard work, special training, or technique they can eliminate their foreign accent.

As non-native speakers of English, these participants thought they would try different instructional strategies and teaching methods to teach their learners in the future through correcting their pronunciation or using mouth shapes, as in Example 37 and 38.

\#37 In English pronunciation class, I will correct my own pronunciation problems. I will use mouth's shapes or mnemonics.

\#38 I would offer my students more opportunities to speak in class and if there is any error, I would correct them instantly in order to help them avoid my own pronunciation weakness.

These pre-service English teachers seem to hold intelligibility to be the main principle in teaching pronunciation, where learners need to make themselves understood (Levis, 2005). Certain types of pronunciation error may have a disproportionate role in impairing comprehensibility, so such errors need to be corrected.

Based on the above analysis, the study has the following findings. First, the pre-service English teachers learned English pronunciation through formal (English education received from kindergarten through college) and informal education (i.e. cram schools, private tutors, language schools, family members). They learned pronunciation through phonics and K. K. phonetic instruction, even though they felt confused about these two systems. Participants learned English pronunciation from NESTs and NNESTs and their focus of instruction varies. Second, participants' common pronunciation problems include accent, $r$, vowels, intonation, word or sentence stress, linking, and consonants. They overcame their pronunciation problems by listening to English related programs, imitating the native English speakers' pronunciation, and through practice. Third, participants did not have the same attitude toward their roles as non-native English speakers regarding pronunciation learning and teaching. On one hand, they thought English is used to communicate. Their own accent is their identity, so they do not have to achieve a native-like accent. However, some participants strived hard to have a native-like accent. Regardless of their attitude or roles as non-native English speakers, participants claimed that one day when they become language teachers, they will apply a variety of instructional strategies to help their potential learners in terms of pronunciation instruction. 


\section{Implications}

Based on the findings of this study, several elements need to be included in pre-service language teacher education in order to prepare these pre-service English teachers to be competent in teaching pronunciation. These elements include clear theoretical concepts about phonics and the K. K. phonetic system, knowledge about language, instructional strategies on pronunciation instruction, and professional identities as in Figure 5.

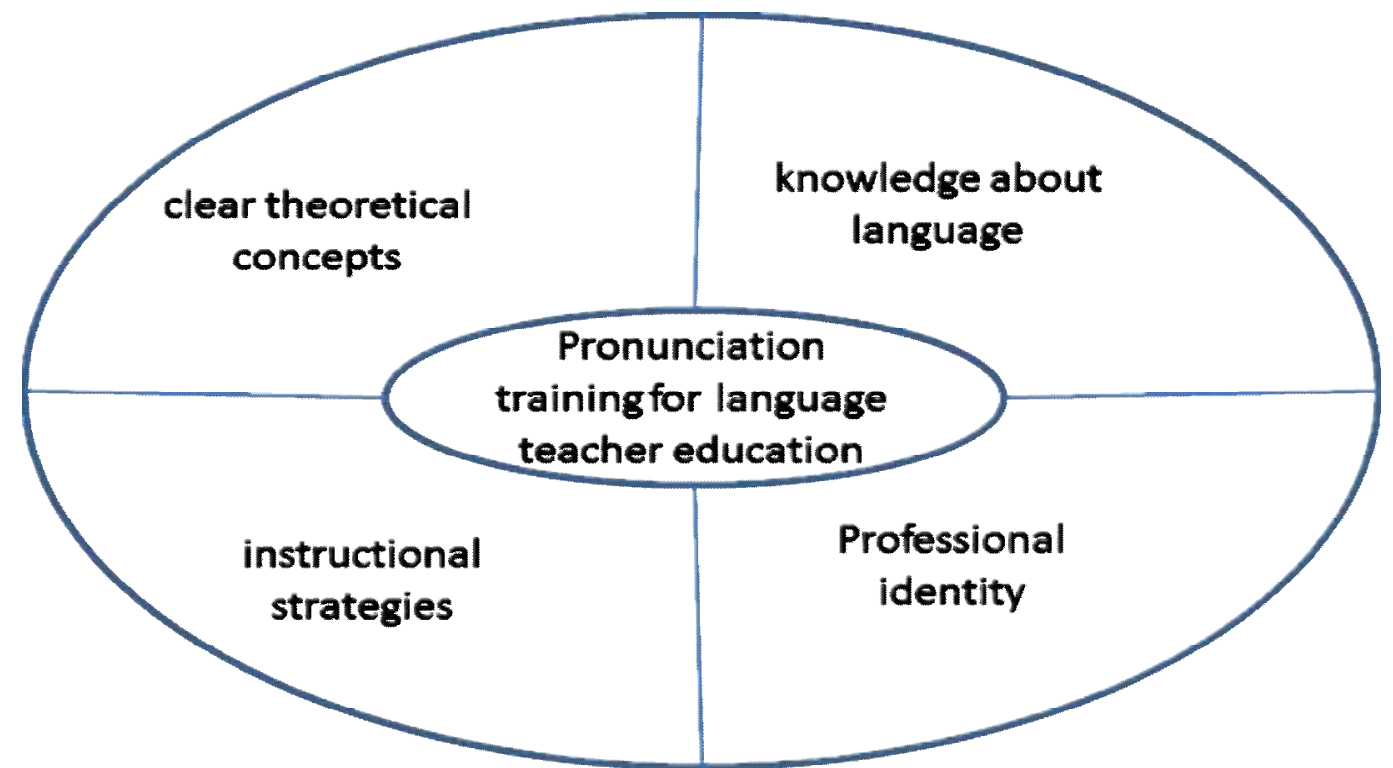

Figure 5. Elements of Pronunciation Training in Language Teacher Education

First, the participants in this study were confused about phonics and the K. K. phonetic system, so clear theoretical concepts on phonics and K. K. should be included in pre-service language teacher education. Lapp and Flood (1997) defines phonics as "the relationship between letters and their corresponding sounds, [which] is very much a part of learning how to read" (p. 696). The purpose of phonics instruction is to help learners "acquire knowledge of the alphabetic system and its use to decode new words and to recognize familiar words accurately and automatically" (National Reading Panel, 2000, p. 2-90). Learning the pronunciation of individual vowels and consonant sounds is not learning English pronunciation. Pronunciation is an integral part of language learning and it is important for communication, so features of pronunciation instruction should include both phonemes (i.e. consonants, vowels) and suprasegmental features (i.e. intonation, stress) (Kelly, 2000).

Second, language teachers need to have knowledge of language (Day \& Conklin, 1992; Fradd \& Lee, 1998; Guntermann, 2002; Mann, 2005; Morain, 1990; Thomas, 1987), also known as "knowledge about language" coined by Bartels (2009), as well as the structure of the English language (i.e. phonology, morphology, syntax, semantics, pragmatic) (Ariza, 2006). Fillmore and Snow (2002) believe that teachers who know how language impacts teaching and learning will have a greater impact on the learning achievement of language learners. They further suggest that each area of linguistic study should be introduced by educational situations in which language is an issue. They provide an example as follows:

For example, the study of phonology could begin with an examination of interference problems that English language learners might have with the English sound system. It might include investigation of topics such as why speakers of Cantonese or Spanish have problems with consonant clusters at the ends of English words like fivesixths, which contains four consonants in a row / siks $\theta /$. (p. 32)

Third, pedagogical competence, teaching methods and instructional strategies should be included in pre-service language teacher education. Theoretical rationale and practical implications of pronunciation teaching approaches, methods, procedures, strategies, and techniques should be covered in language teacher education, assessment, and evaluation (Larsen-Freeman, 1986; Oller, 1993; Richards \& Rodgers, 1982). Kelly (2000) proposes two key sides to pronunciation teaching including the teaching of productive and receptive skills. Learners need to learn to hear the difference between phonemes, so they can carry such knowledge into their production. Multifarious activities and techniques are recommended for pronunciation instruction, from highly focused techniques (i.e. drilling) to more broad-reaching activities (i.e. getting students to notice particular pronunciation features) (Kelly, 2000).

Fourth, professional identities should be included in pre-service language teacher education. Teachers' perceptions of their own professional identity affect their efficacy and professional development as well as their ability and willingness to cope with educational change and to implement innovations in their own teaching practice (Beijaard, Verloop, \& Vermunt, 2000). Therefore, Singh and Richards (2006) suggest that teacher identity should be "woven" through the ideologies, discourses, contents, and approaches of the course, for the individual teacher's own desire to find meaning in becoming a teacher. Golombek and Jordan (2005) call for teacher education programs to help nonnative speaker teachers "imagine alternative identities" (p. 513) for themselves, referring to identities that go beyond restrictive notions of pronunciation intelligibility and employ a variety of factors to establish professional legitimacy. 
This study analyzes 58 non-native pre-service elementary school English teachers' narratives about their pronunciation learning and teaching. An important finding emerges in this study. Regarding their different attitude or roles as nonnative English speakers in terms of language learning and teaching, participants responded that when they become language teachers in the future, they will apply instructional strategies to their pronunciation instruction to help their future students learn pronunciation well. From the perspective of language teacher educators and trainers, this study provides a model with four important elements in pronunciation training to better equip pre-service English teachers with competence in teaching pronunciation. Drawing on previous research on teachers' perceptions on pronunciation instruction and learning, the contribution of this study is to move beyond using survey and interviews as data toward the use of narratives in analyzing pre-service English teachers' learning and teaching pronunciation.

\subsection{Limitations}

As the number of the participants in this study was very small (only 58 participants), the findings of this case study cannot be generalized to a bigger pre-service teacher population. The rich data collection can be used to explain these non-native pre-service elementary school English teachers' perceptions about pronunciation learning in terms of their formal and informal English education, their pronunciation problems, strategies on solving these problems, and their roles as non-native English speakers.

\subsection{Issues for Further Study}

Participants in this study are at different English proficiency levels (intermediate and advanced). A further study can focus on the relationship between pre-service elementary school English teachers' English proficiency levels and their perceptions of pronunciation learning. Moreover, these participants may have different types of English teaching experience, from being a private English tutor, teaching in a language school, teaching in remedial English programs, teaching in English summer or winter camps, etc. Another study can discuss the influence of pre-service elementary school English teachers' teaching experience on their pronunciation learning and teaching.

\section{References}

Andrews, S. (2003). Teacher language: Awareness and the professional knowledge base of the L2 teacher. Language Awareness, 12(2), 81-95. doi: 10.1080/09658410308667068.

Ariza, E. N. W. (2006). What teachers need to know about language acquisition. In Author. Not for ESOL teachers: What every classroom teacher needs to know about the linguistically, culturally, and ethnically diverse students (pp. 87-99). Boston, MA: Allyn \& Bacon.

Avery, P., \& Ehrlich, S. (2002). Teaching American English pronunciation. Oxford, UK: Oxford University Press.

Baker, A. (1982). Introducing English pronunciation: A teacher's guide to tree or three? And ship or sheep? London, UK: Cambridge University Press.

Barkhuizen, G. (2008). A narrative approach to exploring context in language teaching. English Language Teaching Journal, 62(3), 231-239. doi: 10.1093/elt/ccm043

Barkhuizen, G. (2009). Topics, aims, and constraints in English teacher research: A Chinese case study. TESOL Quarterly, 43(1), 113-125. http://www.jstor.org/stable/27784990

Barkhuizen, G. (2010). An extended positioning analysis of a pre-service teacher's better life small story. Applied Linguistics, 31(2), 282-300. doi: 10.1093/applin/amp027

Barkhuizen, G. (2011). Narrative knowledge in TESOL. TESOL Quarterly, 45(3), 391-414. doi: 10.5054/tq.2011.261888

Barkhuizen, G., \& Benson, P. (2008). Narrative reflective writing: “It got easier as I went along.” Brazilian Journal of Applied Linguistics, 8(2), 383-400.

http://dx.doi.org/10.1590/S1984-63982008000200006

Bartels, N. (2005). Researching applied linguistics in language teacher education. In Author. Applied linguistics and language teacher education (pp. 1-18). New York, NY: Springer Science and Business Media, Inc.

Bastug, H. (2010). Perceptions and effectiveness of being a non-native English speaker teacher (NNEST) as a foreigner in Bosnia and Herzegovina. (Unpublished master's thesis). International Burch University, Sarajevo, Bosnia and Herzegovina.

Beckett, G. H., \& Stiefvater, A. (2009). Change in ESL graduate students' perspectives on non-native English-speaker teachers. TESL Canada Journal, 27(1). [Online] Available:

http://teslcanadajournal.ca/index.php/tesl/article/view/1028 (March 28, 2014)

Benke, E., \& Medgyes, P. (2006). Differences in teaching behavior between native and non-native speaker teachers: As seen by learners. In E. Llurda (Ed.), Non-Native language teachers: Perceptions, challenges and contributions to the profession (pp.195-216). New York, NY: Springer.

Beijaard, D., Verloop, N., \& Vermunt, D. J. (2000). Teachers' perceptions of professional identity: An exploratory study from a personal knowledge perspective. Teaching and Teacher Education, 16(7), 749-764. http://dx.doi.org/10.1016/S0742-051X(00)00023-8. 
Braine, G. (2010). NNS English teachers and accents. WATESOL NNEST Caucus Annual Review, 1, 15-20. [Online] Available:

https://docs.google.com/file/d/0Bz-

G2H5Hram7OWI3MDMzMDgtNGM0NS00M2E0LThmNGYtOTQ4Yjk1ZWI3ZDA3/edit?hl=en\&pli=1 (March 28, 2014)

Butler, Y. G. (2007). Factors associated with the notion that native speakers are the ideal language teachers: An examination of elementary school teachers in Japan. JALT Journal, 29(1), 7-40.

Celce-Murcia, M., Brinton, D. M., \& Goodwin J. M. (1996). Teaching pronunciation: A reference for teachers of English to speakers of other languages. Cambridge, UK: Cambridge University Press.

Cenoz, J., \& Lecumberri, M. G. (1999). The acquisition of English pronunciation: Learners' views. International Journal of Applied Linguistics, 9(1), 3-17. doi: 10.1111/j.1473-4192.1999.tb00157.x

Chang, C. W. (2013). Exploring the beliefs of native and non-native English speaking kindergarten teachers in Taiwan. International Journal of Research Studies in Language Learning, 2(5). [Online] Available: http://www.consortiacademia.org/index.php/ijrsll/article/view/171 (March 28, 2014)

Chang, Y. (2001). A study of areas of English pronunciation which pose particular difficulties for Taiwanese EFL students based on the first year students from two-year program of Transworld Institute of Technology. Journal of Transworld Institute of Technology, 20, 95-108.

Chen, S. H., \& Yang, M. N. (2007). Effect of proficiency on Taiwanese EFL learners' pronunciation. Samara AltLinguo E-Journal, 2. [Online] Available:

http://samaraaltlinguo.narod.ru/ejournal/207_chen_yang_2.pdf(March 28, 2014)

Chen, T. E. (1998). The teaching of English pronunciation in Taiwan: A review. Proceedings of the Seventh International Symposium on English Teaching (pp. 269-277). Taipei, Taiwan: Crane.

Chu, C. F. (2006). A comparison study of the effectiveness of teaching English phonics and K. K. phonetic symbols on word pronunciation. (Unpublished master's thesis). National Chengchi Uuniversity, Taipei, Taiwan.

Chung, P. H. (2011). A study of pronunciation instruction on EFL vocational high school students. (Unpublished master's thesis). National Pingtung Institute of Commence, Pingtung, Taiwan.

Day, R., \& Conklin, G. (1992). The knowledge base in ESL/EFL teacher education. Paper presented at the 1992 TESOL Conference, Vancouver, Canada.

Chiu, H. H. (2008). Practical understandings: Teachers' beliefs and practices in pronunciation teaching. (Unpublished master's thesis). University of Texas, Austin, Texas.

Corcoran, J. (2011). Power relations in Brazilian English language teaching. International Journal, 5, 1-26.

Creswell, J. W. (2009). Research design: Qualitative, quantitative, and mixed methods approach. Thousand Oaks, CA: Sage Publications.

Edwards, S (2009) Experiences and perceptions of nonnative-speaker teacher trainees on a TESOL programme in New Zealand. In: LED (Language Education and Diversity) 2007 Conference Proceedings. Hamilton, New Zealand: University of Waikato.

Faez, F. (2010). Linguistic and cultural adaption of internationally educated teacher candidates. Canadian Journal of Education and Administration and Policy, 100. [Online] Available:

https://umanitoba.ca/publications/cjeap/articles/faez-iet.html (March 28, 2014)

Fillmore, L.W., \& Snow, C. (2000). What teachers need to know about language. Washington, DC: Center for Applied Linguistics.

Fradd, S. H., \& Lee, O. (1998). Development of a knowledge base for ESOL teacher education. Teaching and Teacher Education, 14(7), 761-773. http://dx.doi.org/10.1016/S0742-051X(98)00023-7

Fu, Y. C. (1995). Teaching pronunciation through K.K. phonetic symbols in junior high school. National Institute for Compilation and Translation Communication, 8(1), 46-48.

Golombek, P. R., \& Johnson, K. E. (2004). Narrative inquiry as a mediational space: Examining emotional and cognitive dissonance in second-language teachers' development. Teachers and Teaching: Theory and Practice, 10(3), 307-327. doi:10.1080/1354060042000204388

Golombek, P., \& Jordan, S. R. (2005). Becoming black lambs not parrots: A poststructuralist orientations to intelligibility and identity. TESOL Quarterly, 39(3), 513-534. doi: 10.2307/3588492

Guntermann, G. (2002). Developing tomorrow's teachers of world languages. ERIC Digest 350880. [Online] Available: http://www.ericdigests.org/1992-1/world.htm (March 28, 2014)

Hadid, D. (2004). Students' perceptions of their native English speaking teachers and non-native English speaking teachers' teaching practices in two Lebanese private schools. (Unpublished master's thesis). American University of Beirut, Beirut, Lebanon.

Harmer, J. (2007). The practice of English language teaching. Essex, England: Pearson Education Limited. 
He, D., \& Miller, L. (2011). English teacher preference: The case of China's non-English major students. World Englishes, 30(3), 428-433. doi: 10.1111/j.1467-971X.2011.01716.x

Holliday, A. (2005). The struggle to teach English as an international language. Oxford, UK: Oxford University Press.

Hsieh, S. H. (2009). Students' listening ability of distinguishing long and short vowels in phonics and K. K. teaching method. (Unpublished master's thesis). Southern Taiwan University of Science and Technology, Tainan City, Taiwan.

Hsu, H. F. (2003). Effects of three pronunciation teaching methods on developing children's phonemic awareness, word identification, and spelling abilities. (Unpublished master's thesis). National Taiwan Normal University, Taipei, Taiwa.

Hsu, L. H. (2000). A study on phonics and phonetic symbols in ELT. (Unpublished master's thesis). National Taiwan Normal University, Taipei, Taiwan.

Huang, H. L., \& Radant, J. (2009). Chinese phonotactic patterns and the pronunciation difficulties of MandarinSpeaking EFL learners. The Asian EFL Journal Quarterly, 11(4), 148-168.

Huang, S. L. (2002). An experimental study of the effects of phonics instruction on the acquisition of phonological awareness of junior high school students in Taiwan. (Unpublished master's thesis). National Taiwan Normal University, Taipei, Taiwan.

Huang, T. L. (2001). Taiwanese and American English segmental phonemes: A contrastive study. Journal of Jin-Wen Institute of Technology, 2, 29-55.

Hung, S. K. (1998). A comparison of two methods, K.K. phonetic symbols and phonics, in teaching English to children. (Unpublished master's thesis). National Kaohsiung Normal University, Kaohsiung, Taiwan.

Jenkins, J. (2005). Implementing an international approach to English pronunciation: The role of teacher attitudes and identity. TESOL Quarterly, 39(3), 535-543. doi: 10.2307/3588493

Karakuzu, M., \& Akdoğan, M. (2010) Effectiveness of teaching English in a foreign country by a non-native speaker English teacher (NNEST). Paper presented at the Second International Symposium on Sustainable Development, Sarajevo.

Kasai, M., Lee, J. A., \& Kim, S. (2011). Secondary EFL students' perceptions of native and nonnative Englishspeaking teachers in Japan and Korea. The Asia EFL Journal, 13(3), 272-300. [Online] Available: http://www.asianefl-journal.com/PDF/September-2011.pdf (March 28, 2014)

Kelch, K., \& Santan-Williamson, E. (2002). ESL students' attitudes toward native- and nonnative-speaking instructors' accent. CATESOL Journal, 14(1), 57-72.

Kelly, G. (2000). How to teach pronunciation. Essex, England: Pearson Longman.

Kleinsasser, R. C. (1993). A tale of two technical cultures: Foreign language teaching. Teaching and Teacher Education, 9(4), 373-383. http://dx.doi.org/10.1016/0742-051X(93)90004-Z

Kumaravadivelu, B. (2008, June 7). Accent on the wrong issue when it comes to speaking English. Education Post, E4.

Lapp, D., \& Flood, J. (1997). Where is the phonics? Making the case (again) for integrated code instruction. The Reading Teacher, 10(5), 696-700.

Larsen-Freeman, D. (1986). Techniques and principles in language teaching. New York, NY: Oxford University Press.

Lasagabaster, D., \& Sierra, J.M. (2005). What do students think about the pros and cons of having a native speaker teacher. In E. Llurda (Ed.), Non-native language teachers: Perceptions, challenges and contributions to the profession (pp. 217-241). New York, NY: Springer.

LeCompte, M. D., \& Schensul, J. J. (1999). Designing and conducting ethnographic research. Walnut Creek, CA: AltaMira.

Levis, J. M. (2005). Changing contexts and shifting paradigms in pronunciation teaching. TESOL Quarterly, 39(3), 369-377. doi: $10.2307 / 3588485$

Li, C. C. (1981). Basic concepts of teaching English pronunciation. English Teaching \& Learning, 5(4), 14-21.

Lin, C. Y. (2010). English teachers' beliefs and practices of pronunciation teaching: A qualitative study on elementary school teachers. (Unpublished master's thesis). National Yulin University of Science and Technology, Yulin, Taiwan.

Lin, H. H. (2009). Troubleshooting through collaborative action research: Enhancing novice teacher K.K. phonetics instruction in elementary classrooms. Kaohsiung Normal University Journal, 27, 61-82.

Lin, Y. C. (2001). The effects of the phonics teaching method with or without K. K. phonetic symbols in teaching pronunciation to EFL adult learners. (Unpublished master's thesis). National Changhua University of Education, Changhua County, Taiwan.

Liu, C. J. (2009). Comparison of the effects between phonics instruction and phonetic instruction to the fifth graders on the accuracy of word pronunciation instruction on phonetic instruction to the fifth graders on the accuracy of word pronunciation. (Unpublished master's thesis). National Taipei University of Education, Taipei, Taiwan. 
Liu, J. (2009). Complexities and challenges in training nonnative English-speaking teachers: State of the art. In (Eds.) CamTESOL Conference on English Language Teaching: Selected papers.

Llurda, E. (2006). Non-native language teachers: Perceptions, challenges and contributions to the profession. New York, NY: Springer.

Llurda, E. \& Huguet, A. (2003). Self-awareness in NNS EFL primary and secondary school teachers. Language Awareness, 12 (3\&4), 220-233. doi: 10.1080/09658410308667078

Mahboob, A. (2004). Native or nonnative: What do students enrolled in an intensive English program think? In L. Kamhi-Stein (Ed.), Learning and teaching from experience: Perspectives on nonnative English-speaking professionals (pp. 121-147). Ann Arbor, MI: Michigan University Press.

Mann, S. (2005). The language teacher's development. Language Teaching, 38, 103-119.

Mcneely, S. R. \& Mertz, N. T. (1991) Cognitive constructs of pre-service teachers: How students think about teaching before formal preparation. Paper presented at the Annual Meeting of the American Educational Research Association, Boston, MA.

Meadows, B., \& Muramatsu, Y. (2007). Native speaker or non-native speaker teacher?" A report of student preferences in four different foreign language classrooms. Arizona Working Papers in SLA \& Teaching, 14, 95-109. [Online] Available:

http://slat.arizona.edu/sites/slat/files/page/awp14muramatsu.pdf (March 28, 2014)

Merriam, S.B. (2009). Qualitative research: A guide to design and implementation. San Francisco, CA: Jossey-Bass.

Miller, S. F. (2006). Targeting pronunciation. Boston, MA: Houghton Mifflin.

Ministry of Education (2001). Guidelines on English teaching activity designs and assessments in elementary and junior high school. Taipei, Taiwan: Ministry of Education.

Ministry of Education (2005). Guidelines on English teaching activity designs and assessments in elementary and junior high school. Taipei, Taiwan: Ministry of Education.

Miyasone, M. (2007). The role of non-native English speaking teachers for elementary school English. In The Second Biennial International Conference on Teaching and Learning of English in Asia: Exploring New Frontiers (TELiA2) (pp. 1-10). Sintok, Malaysia: Universiti Utara Malaysia.

Morain, G. (1990). Preparing foreign language teachers: problems and possibilities. ADEFL Bulletin, 21(2), 20-24. doi:10.1632/adfl.21.2.20

Morley, J. (1991). The pronunciation component in teaching English to speakers of other languages.

TESOL Quarterly, 25(3), 481-520. doi: 10.2307/3586981

Muramatsu, Y. (2008). The role of native-speaker status and cultural background: A multidimensional case study of teacher-student interaction in English composition classes. (Unpublished dissertation). University of Arizona, Tucson, Arizona.

National Reading Panel. (2000). Chapter 2, Part II: Phonics instruction. In Author, Teaching children to read, (pp. 289-2-176). Rockville, MD: Author.

Oller, J. W. (1993). Methods that work: Ideas for literacy and language teachers. Boston, MA: Heinle \& Heinle.

Reis, D. (2011). Non-native English-speaking teachers (NNESTs) and professional legitimacy: A socialcultural theoretical perspective on identify transformation. International Journal of the Sociology of Language, 208, 139-160. doi: $10.1515 /$ ijsl.2011.016

Richards, J. C., \& Rodgers, T.S. (1982). Method: Approach, design and procedure. TESOL Quarterly, 16(2), 153168. doi: $10.2307 / 3586789$

Shibuya, A. (2012). Non-center English teachers in Japan: A case study. Paper presented at JALT 2012, Shizuoka, Japan.

Sifakis, N. C., \& Sougari, A. (2005). Pronunciation issues and EIL pedagogy in the periphery: A survey of Greek State school teachers' beliefs. TESOL Quarterly, 39(3), 467-488. doi: 10.2307/3588490

Singh, G., \& Richards, J. (2009). Teaching and learning in the course room. In A. Burns. \& J. C. Richards (Eds.), The Cambridge guide to second language teacher education (PP. 201-208). New York, NY: Cambridge University Press.

Sung, C. C. (2010). Native or non-native? Exploring Hong Kong students' perspectives. In G. Bota., H. Hargreaves. (Eds.). Paper from the Lancaster University Postgraduate Conference in Linguistics \& Language Teaching, 4 (pp. 118).

Swan, M. \& Smith, B. (Eds.) (1990). Learner English: A teacher's guide to interference and other problems. Cambridge: Cambridge University Press.

Tang, C. (1997). The identity of the nonnative ESL teacher on the power and status of non-native ESL teachers. TESOL Quarterly, 31(3), 577-583. doi: 10.2307/3587840

Thomas, A. L. (1987). Language teacher competence and language teacher education. In R. Bowers (Ed.), Language teacher education: An integrated approach for EFL teachers (pp. 33-42). Oxford, UK: Modern English Publications. 
Tseng, M. J. (2011). English Pronunciation Teaching: Implications of Teaching English Pronunciation in Taiwan. (Unpublished master's thesis). Southern Taiwan University of Technology, Tainan, Taiwan.

Tsui, A. (2007). Complexities of identity formation: A narrative inquiry of an EFL teacher. TESOL Quarterly, 41(4), 657-680. doi: 10.1002/j.1545-7249.2007.tb00098.x

Tzwei, C. R. (1987). An error analysis of English consonant pronunciation of Chinese University students. In Huang T. L. et al (Eds). Papers from the Forth Conference on English Teaching and Learning in the R. O. C. Taipei, Taiwan: Crane.

Vodopija-Krastanovic, I. (2012). NESTs versus non-NESTs: Rethinking English-language teacher identities. In J. I. Huttner., B. Mehlmauer-Larcher, S. Reichl., \& B. Schiftner (Eds.). Theory and practice in EFL teacher education: Bridge the gap, (pp. 207-227). Ontario, Canada: Multilingual Matters.

Warford, M. K., \& Reeves, J. (2003). Falling into it: Novice TESOL teacher thinking. Teachers and Teaching: Theory and Practice, 9(1), 47-65. doi: 10.1080/1354060032000049904

Wu, J. S. (2005). A contrastive phonology of Mandarin Chinese and American English. [Online] Available:

http://web.ncyu.edu.tw/ wujs\%20/Courses/Contrastive\%20Analysis/ch\%27u phonology.pdf (March 28, 2014)

Wu, J. H., \& Ke, I. C. (2009). Haunting native speakerism? Students perceptions toward native speaking English teachers. English Language Teaching, 2(3), 44-52. [Online] Available:

http://www.ccsenet.org/journal/index.php/elt/article/view/2715/3284 (March 28, 2014)

Yan, H. (2010). Teaching as a native (Chinese) speaker and a nonnative (English) speaker: Different identities, similar needs. WATESOL NNEST Caucus Annual Review, 1, 70-98. [Online] Available: https://docs.google.com/file/d/0BzG2H5Hram7MzU3OTQzMDktZTQ1Zi00NWFjLTg0NWEtYjI1OWU5ZjgwMzlj/edit?hl=en\&pli=1(March 28, 2014)

Yeh, L. H. (2005). The study of exploring the effects of using K.K. phonetic symbols on English language teaching-A case study of six graders. (Unpublished master's thesis). National Sun Yat-Sen university, Kaohsiung, Taiwan. 